\title{
THE LABOUR CHURCH MOVEMENT
}

The conference held at Bradford in 1893 to form an Independent Labour Party was accompanied by a Labour Church service which some 5,000 people attended. ${ }^{1}$ It was organised by John Trevor, who in $189 \mathrm{I} \mathrm{had} \mathrm{left} \mathrm{his} \mathrm{Unitarian} \mathrm{pulpit} \mathrm{in} \mathrm{Manchester} \mathrm{and} \mathrm{founded} \mathrm{the}$ first Labour Church. "God in the Labour Movement", he explained "- working through it, as once he worked through Christianity, for the further salvation of the world - that was the simple conception that I had been seeking, and which at last came to me..." 2 The fullest account of this movement created by Trevor has been given in H. M. Pelling's The Origins of the Labour Party, where it is sensibly cited as a stage in the "transfer of social energy from religion to politics." 3 The purpose of the present article is to dissent from certain judgments made by Mr. Pelling and to suggest, in some particulars, a different interpretation.

According to Mr. Pelling the Labour Churches "gained support merely as a short-lived protest against the link which the Nonconformist churches had established with the middle class, and in particular against the alliance with the Liberal Party." 4 This conclusion can certainly be supported by a study of some Labour Churches. Trevor's own decision to leave the Unitarians was provoked by a talk with a working man who had left his chapel because he could not stand the social climate of the congregation. At Bolton, the oldest Congregational body in the town formed itself into a Labour Church, pastor and all, after a series of addresses in the chapel by the union

1 Labour Prophet, Feb. I 893, 16.

2 J. Trevor, My quest for God (1897), 24I.

3 H. M. Pelling, The Origins of the Labour Party, r880-1900 (1954), 139.

Ibid., I II-2. 
leader Ben Tillett. ${ }^{1}$ At Bradford, it was Tillett's candidature in the parliamentary election of 1892 that occasioned the founding of a Labour Church. "Mr. Tillett and his followers", wrote the correspondent of a Nonconformist journal, "by a strange process of reasoning, came to the conclusion that the ministers and the churches were opposed to their labour movement." 2 The reasoning was not so strange: Bradford Dissent made its political allegiance plain when twelve Nonconformist ministers sat on the platform at a meeting held to support Tillett's Liberal opponent. Fred Jowett, president of the Bradford Labour Union, got up and told the ministers: "If you persist in opposing the Labour Movement, there will soon be more reason than ever to complain of the absence of working men from your chapels. We shall establish our own Labour Church." 3 They did; and the Bradford Labour Church was soon the largest in the country.

Nevertheless, the Labour Churches were not a revolt against Nonconformity alone. In their ranks and their leadership were not only former Unitarians like Trevor, Quakers like Sam Hobson, Congregationalists like the group at Bolton, and Wesleyans like Seth Ackroyd at Hull; there were also many who had come from the Church of England. R. A. Beckett, who for a while edited the Labour Churches' magazine The Labour Prophet, had once been a Unitarian lay preacher; but he was the son of an Anglican clergyman, and he had been set on the path to socialism by reading F. D. Maurice. ${ }^{4}$ The first secretary of the Darlington Labour Church, A. W. Hildreth, was brought up in the Church of England. ${ }^{5}$ Tom Groom, secretary for some years of the Birmingham Labour Church, had been a member of the Guild of St. Matthew, the society of radical Anglicans founded by Stewart Headlam. ${ }^{6}$ Another leader at Birmingham, J. A. Fallows, had been a clergyman in the Church of England. ${ }^{7}$ So, almost, had Fred Brocklehurst, the first general secretary of the Labour Church Union and next to Trevor the hardest of workers for the movement. After leaving Cambridge, Brocklehurst was on the point of taking holy orders when he turned instead to the Labour Church and the I.L.P. Walter Morse, secretary of the Labour Church Union in 1896 , had been a regular worshipper in the Church of England until he joined the Leeds Labour Church; he said that "the very easy and

1 Labour Prophet, May $1892,38$.

2 Christian World, 4 Aug. 1892,635 .

3 Quoted in: F. Brockway, Socialism over sixty years (I946), 4 I.

4 Labour Annual, 1898, 93 .

5 Labour Prophet, June i 896, 97.

- J. Clayton, The rise and decline of socialism in Great Britain, 1884-1924 (1926), 98.

7 Labour Church Record, Oct. 1899, 5 . 
ineffectual way" in which Anglicans dealt with social injustice, "and their failure to understand what was the real evil", led him towards the Labour Church. ${ }^{1}$ The people named here contributed a high proportion of the total energy in the movement. It may be that people in the Labour Churches felt more bitterly towards Nonconformity, which had once seemed and which still purported to be the friend of the common people, than towards the Church of England, whose intimate association with the ruling classes had been long taken for granted by radicals. But in the Labour Church as in the political labour movement, attacks on the social attitudes of organized Christianity were made less often against this or that church than against the churches at large. "The Church worships respectability", wrote Keir Hardie, "and puts its ban on poverty... I speak of no particular sect or denomination. I discern little to choose from in any of them." 2 He was writing in The Labour Prophet and expressing the view predominant among its writers and readers, recruited as they were from both church and chapel.

In Trevor's mind the Christian churches were equivalent not only in their "dependence on middle-class support", but also in being "too muddled up with Theology and Christology." 3 "The historic churches", he believed, "mostly declare that God was on this earth nearly nineteen centuries back. The Labour Church was founded for the distinct purpose of declaring that God is at work, here and now, in the heart of the Labour movement; and that the religion of today consists in co-operating with the divine energy which is still operating on our planet." "Even if a miracle made the older churches socialist, adherence to outworn religious dogma would still strangle their message.5 When he distinguished between "religion" and "theology" Trevor was very much a man of his age. Many of the people who had surrendered their belief in Christian dogma - whether to the biblical scholarship of Tubingen, the positivism of Comte, the geology of Lyell and biology of Darwin, or to some other of the Victorian solvents of orthodoxy - found it comforting to think that only the husk of formal doctrine must be abandoned, leaving a kernel of religious faith. It did not worry doubters who stopped short of agnosticism that this faith was vague: they gladly sacrificed the precision of belief which only dogma made possible, for they believed

1 Labour Prophet, Aug. 1896, I 29.

2 Ibid., Nov. 1892,8 5-6.

3 J. Trevor, An Independent Labour Party, 1892 , 1 r.

4 Labour Prophet Sept. 1894, 120.

5 Ibid., Oct. I 894, $136-7$. 
such precision to be bogus. They might or might not call themselves Christians. Their position was summed up by Robert Blatchford in I $88 \mathrm{~s}$, when he described his religion as the Christianity of Abou Ben Adhem. ${ }^{1}$ Once "theology" was ruled out, differences over whether God was a person or a principle, whether Jesus was or was not divine, were matters of taste rather than subjects for discussion. It is true but it may be misleading to say that Keir Hardie was a Christian, for a more cordial response could be expected in the Labour Church than in any traditional Christian church to his characteristic remark: "The more a man knows about theology the less he is likely to know about Christianity." 2 People who clung to "theology" could join the Labour Church if they wished, but they must not expect to find there any recognition or discussion of theological doctrine. In this church, dogmas were anathema.

Trevor was nevertheless quite serious when he called his movement a church. It was his conviction that labour needed to be independent of the Church of England and Nonconformity just as it needed to be independent of the Conservatives and the Liberals. In neither case, moreover, must it be content with mere emancipation: it must form an Independent Labour Party to win social justice, and a Labour Church to save its soul. If his enterprise was to succeed, Trevor had to persuade a large number of social radicals to agree with him about its purpose.

\section{II}

In discussing the decline of the Labour Churches, Mr. Pelling suggests the following factors:

(I) "the success of the more convivial Clarion Fellowship and the other forms of social organisation that Blatchford sponsored, for instance the Clarion Cycling Clubs that became the rage in the North of England."

(2) “... Blatchford's ostentatious abandonment of religious faith in the early years of the present century, and his publication of God and My Neighbour (1903), which caused much controversy in Socialist circles."

(3) "the steadily changing attitude of the denominational churches to the social problem." 3

Mr. Pelling notes that the first Clarion Cycling Club was formed at a meeting in the Birmingham Labour Church in 1894. There is no evidence in the minutes of this Church of any decline in attendances

1 Quoted in: A. M. Thompson, Here I lie (1937), 54.

2 Labour Leader, 10 Nov, $1894,2$.

3 H. M. Pelling, op. cit., I 46. 
once the Clarion Cycling Club was formed; there is evidence ${ }_{2}$ however, that the Club co-operated harmoniously with the Birmingham Labour Church. ${ }^{1}$ The reasons for falling attendances during 1897 and 1898 were discussed at some length by members of the Birmingham Labour Church, but the minutes do not refer to the Clarion Cycling Club as a factor. Nor has the writer seen the Clubs mentioned in any published discussion, by members of other Labour Churches, of the reasons for their decline. It is probably true that the rise of secular entertainments, including cycling, tended to reduce attendances at churches of all sorts. But since this tendency was observed often before the first Labour Church existed, it can hardly be invoked to explain the decline of a movement which was not founded until i 891 , which increased its adherents for a few years, and which then slowly declined. ${ }^{2}$ The Clarion Fellowship was not formed until 1900. If it bore any relation to the Labour Churches, it was more a response to their decline than a cause of it. As for Blatchford himself, his attack on religion did not come until the Labour Churches had lost most of their momentum. Nor did social attitudes within the Christian churches change so rapidly after $189 \mathrm{I}$ that people hostile to them in 1890 could see them as friends by 1900 (or even 1910). It is hard to think of any social radical who was critical of institutional Christianity in 1890 and satisfied with it ten or twenty years later. (Although George Lansbury appears to have returned to the Church of England about 1900 after some years away from it ${ }^{3}$, he is no exception. Inside or out, he was stern about the social attitudes of Church leaders). The Labour Church movement was not a structure that collapsed under external blows: it subsided because the architect was never able to get it properly built.

In a Labour Church there was no Bible, no pulpit, no priesthood but the priesthood of believers: each Church had simply a chairman with no special status. Having decided to abandon conventional forms of worship, the members of Labour Churches had now to fashion their own. A Nonconformist reporter described with faint amusement one of the first services at Manchester:

1 Birmingham Labour Church, minutes of executive committee meeting, 7 June r 895 .

2 In Labour Church publications there are references to some 50 churches in England (slightly more than half of them in Lancashire and the West Riding of Yorkshire), I in Wales and 4 in Scotland. At least 37 of the churches were established by 1896 , and in no subsequent year do more than 2 appear to have been formed. In 1898 The Labour Prophet (monthly) had to be abandoned for lack of support, and was replaced by a smaller quarterly, The Labour Church Record, which in turn disappeared in 1902, after the secretary of a Labour Church had written in one of the last issues (April I901, 4): "I find Labour Churches generally weak, unbusiness-like, and quarrelsome".

3 R. Postgate, The life of George Lansbury (r95 I), 54-5. 
"The band 'played the people in', and then followed a hymn. The lesson was taken from 'Looking Backward', - the parable about the rose bush being read, succeeded by a solo, 'Nazareth'. Then there was a hymn (?) of Sir G. Duff's. Ben Tillett then spoke, and was listened to with breathless attention by his audience of 'all sorts and conditions of men'. Undoubtedly the most touching incident of the afternoon was the loud outburst of applause which greeted the name of Christ when it was first mentioned in the afternoon service by Mr. Tillett." 1

Forms of service were usually similar to this one. Passages from suitable authors were printed in The Labour Prophet for use as readings. "Unfortunately", wrote Trevor, "the Bible is so frightfully and falsely conventionalized, that it is difficult to make a Bible reading a real and helpful thing to a Labour Church audience." 2 The authors used instead were often those whose poetry appeared in Labour Church Hymn Books ${ }^{3}$ - writers like Lowell, Emerson, Longfellow, Whittier, Matthew Arnold, Morris, Carpenter and Charles Kingsley. The first Labour Church Hymn Book (1892) contained a few hymns found also in orthodox Christian hymnals, but none in which specifically Christian doctrine is proclaimed. Newman's "Lead, Kindly Light", for example, was sung in Labour Churches; but there is no word in that hymn to which an agnostic could object. Jesus was named once in this collection, in a verse by Whittier. Some mentioned God, and others spoke the language of secular radicalism, good cheer, or homely - even conservative morality. ("Be kind to thy father - for when thou wert young, Who lov'd thee more fondly than he?") Two hymns were clearly written to the music of the national anthem, one patriotic ("God bless our native land") and the other more class-conscious ("God save the working man").

Trevor recommended in 1895 that three hymns should be sung at a service, and that the service should end with a benediction. Some Christian critics had noticed that Labour Church members tended to leave before a service ended. Trevor seems to have felt that a formal benediction might prevent this habit: "when it is the real thing", he suggested, "and when the audience keep their seats to the close, it should give an added sense of devotion." "At his own church in

1 British Weekly, s Nov. 1891, 2 I.

2 Labour Prophet, June 1 895, 89.

3 A Labour Church Hymn Book was printed in 1892 and another in 1906 . The Birmingham Labour Church printed its own in 1894 , and a number of Churches printed sheets of hymns from time to time.

4 Labour Prophet, June 1895, 89. 
Manchester, the benediction was: "May the strength and joy of God's presence be with all who love their brethren in sincerity. Amen." 1 Should there be prayers? Again, Trevor thought so, finding in prayer "an expression of my religious life... an intensely real thing." 2 He did not even think prayer incompatible with complete unbelief: "We have heard even an Atheist regret deeply that there was no prayer at one of our Labour Church Services." 3 The absence of prayer, Trevor believed, was "so distinct a weakness in a religious service, that it should not be lightly abandoned." 4 Lightly or not, many of the churches did without it. In some there might be prayer or no prayer, depending on the chairman's inclination and ability to compose..$^{5}$ Even if the chairman wanted prayer, a reluctant speaker might prevent it. Sam Hobson was once alarmed when addressing the Bradford Labour Church by being asked to pray aloud. Remembering that he was by origin a Quaker, he explained that he could not pray unless the Spirit commanded. The Spirit bade silence. "Thus at one stroke", Hobson wrote, "I saved myself from too obviously playing the hypocrite and acquired a reputation for piety."

Whether or not the movement could endure without prayer, it could not survive without the fellowship, the joy in corporate association, which so many recruits to the Labour Churches had failed to find in the older sects. Reports of some early services suggested that such a spirit was being achieved. When the Unitarian Philip Wicksteed spoke in the Manchester Labour Church he observed a freshness and gaiety that delighted him; ${ }^{7}$ and at Bolton, so the secretary of the Labour Church said in I893, "the heartiness and vigour with which Labour hymns are sung is in pleasing contrast to the conventional style of most churches and chapels." 8 Trevor was not satisfied. "Joy needs wedding to religion", he wrote in $\mathrm{I} 893$; “...even our services are horribly dull and gloomy compared with the bright joyousness of a sunny day in spring." 9 The secretary at Halifax reported in 1894 "a growing feeling among the members of the Labour Church that something must be done to break the monotony of the cut-and-dried

1 Ibid.

2 Ibid., May I 893, 39.

3 Ibid., June I 895,89 .

4 Ibid.

Ibid., May 1 893, 39; March 1898 , I66.

6. Hobson, Pilgrim to the left (1938), 4 r.

7 Manchester Guardian, quoted in Labour Prophet, Fcb. 1892, 10.

8 Labour Prophet, Aug. 1893, 80.

- Ibid., June 1893, so. 
form of service to which we have become accustomed." 1 Bands and choirs were begun by some groups in the hope that they would foster a congregational spirit. At Birmingham in 1895 , when a member urged the necessity of "developing a closer bond of sympathy among L. C. members", the committee responded by holding a social "at $6 \mathrm{~d}$. each to include Tea and Kiss in the Ring." 2 When Herbert Casson, the former Methodist minister who had planted the Labour Church movement in America, inspected the English Labour Churches in I 897 , he was depressed by the dinginess of the halls borrowed or hired for services, the dullness of the singing, and the introverted atmosphere in which no stranger could feel welcome. ${ }^{3}$ Coolness to strangers had been a constant charge against the respectable congregations of orthodox worshippers. It was ironical that it should be noticed so soon in the Labour Church. The president of the Labour Church Union in 1898 referred seriously to the problem. "Don't break up into little cliques after a meeting", he exhorted members, "perhaps looking at the strangers and saying you wonder who they are." 4 He might have been speaking of Salem Chapel.

Among obvious sources of cohesion in Christian churches were the ceremonies of baptism, marriage and burial. At least one Labour Church, in Leeds, appears to have looked to such ceremonies as a way of binding the life of the family to the life of the association. Leeds had its first christening (this was the word used) in I 895 .

"Our president officiated, who, in a little impressive speech, gave the child its name (Alice), hoping that when it grew so as to be able to take its place in the Battle of Life, she would be found in the ranks of the 'despised', if they be fighting for Love, Truth and Justice." 5

A similar service was reported from the same Church in 1897 , called this time "an interesting ceremony equivalent to the orthodox baptism..." The Leeds Church was also registered for solemnizing matrimony; but in this it was alone. ${ }^{7}$ Burials and possibly baptisms were conducted occasionally at other Labour Churches. At Halifax in 1894 the members were "most troubled" whether to perform

1 Ibid., Feb. $1894,32$.

2 Birmingham Labour Church, minutes of members' meeting, 25 Jan. I895; ibid., minutes of executive committee meeting, I Feb. 1895.

3 Labour Prophet, Dec. I 897, I 4 O.

4 Ibid., July I $898,195$.

5 Ibid., May I 895,79 .

6 Ibid., Dec. I $897,140$.

7 Ibid. 
baptisms, but "managed to steer clear of such service." 1 One reason for wanting to steer clear was that it might have been difficult to have baptisms, marriage and burial services without giving the celebrant, whether formally or not, a ministerial status which would have conflicted with the deep anti-clericalism of the movement. The Labour Church ideal was an exacting one: to reject the forms and ceremonies of other churches while preserving the fellowship and zest found in the most lively of them. The secretary at Darlington spoke wistfully of a spirit animating some Nonconformist congregations:

"We may discard their ceremonies and denounce them for distorting the teachings of Christ; but until we become inspired with a faith in our mission like unto the faith they have in theirs, we shall be little better than "children crying in the wilderness'." 2

Nor could the doctrinal issue be dismissed as easily as Trevor had hoped. It was a noble vision that saw in the Labour Church "the Great Catholic Church of Humanity"; but beyond a certain point catholicity of opinion could endanger the identity of the movement. Where should this point be fixed? What limits should be set to eclecticism? "How can the Labour Church", as one member put it, "be broad enough to embrace all, without being so indefinite as to lose all cohesion and force? That is the real problem before us." 4 It was easier to say what the religion of the Labour Church was not than to say what it was. When they attempted to affirm their beliefs with some precision, Labour Church leaders disagreed sharply with each other; and these differences had important practical consequences. Trevor, although discarding "theology", wanted to keep the word "God", believing that it expressed "far better than any other word the Supreme Power we all must recognise..." 5 Others, among whom Fred Brocklehurst was most prominent, wanted to recognize no such thing. Trevor was willing to make some concessions to secularist opinion: the phrase "God is our King" disappeared from the front page of The Labour Prophet after four issues, to be replaced by Mazzini's "Let Labour be the basis of civil society". But he wanted the name of God retained in the statement of principles adopted by the Labour Church Union. In 1894 it was saved by the narrowest possible margin, when nine out of twenty members of the Union's committee voted instead for a statement drawn up by Brocklehurst that referred only to "the moral and ethical aspect of the Labour

1 Ibid., Sep. 1894, 128.

2 Ibid.

${ }^{3}$ Ibid., June I 896,90 .

4 Ibid., March 1898, I62.

5 Ibid., Aug. 1893, 74 . 
movement." Trevor and Brocklehurst argued this question so constantly that Sam Hobson's main task at Labour Church Union meetings, according to his autobiography, was to keep peace between the two men, "both of whom were heavily inoculated with odium theologicum"."

Brocklehurst really wanted the Labour Churches to work in practical ways for social justice, especially by harmonising the different wings of organized labour. ${ }^{3}$ It seemed to Trevor that he was trying to turn the movement away from the very task which made it a church: the effort "to satisfy the cravings of the human heart for God." 4 'Trevor did not argue that this religious mission was incompatible with piecemeal reformist activities. The Church at Manchester under his chairmanship went in for a modest amount of philanthropy; ${ }^{5}$ the "Cinderella" work of several churches - work among poor children, especially offering them holidays and entertainment - went on with his blessing; ${ }^{6}$ and he was not disturbed that the Bradford Church should collect money for dockers on strike, ${ }^{7}$ or that the Hanley Church should campaign against poisonous conditions in the potteries. ${ }^{8}$ He welcomed, moreover, a large measure of secular socialist oratory from Labour Church platforms. But he was afraid that social reform might become an aim which the Labour Church pursued heedless of its spiritual life. "The Labour Church", wrote Trevor in I894, "is in danger of being too much immersed in the secularism and materialism necessarily and rightly attaching to a political movement". ${ }^{9}$ As time went on he grew convinced that this was the greatest danger of all. In the view represented by Brocklehurst, Trevor saw a grave threat not only to the spirituality of the movement, but to its existence. "Unless the Labour Church can do the work of the churches", he declared, "while it also carries out all the harmonising effects which our General Secretary [Brocklehurst] presents to us, it cannot justify its existence. It will be no more than a Fabian Ethical Society, and will rightly cease to be." 10

1 Ibid., Dec. I 894, 171 .

2 Hobson, op. cit., 40-1. Hobson does not say what they quarrelled about, but this is plain from reports of meetings.

3 See, for example, Labour Prophet, May I 894, s2.

4 Ibid., Oct. $1893,100$.

5 Ibid., May 1 892,40 ; Dec. $1894,165$.

6 Cinderclla Clubs were invented by Blatchford when he was on the Sunday Chronicle in 1889. (L. Thompson, Portrait of an Englishman: Robert Blatchford [i95I], 62). 'They were taken up in several Labour Churches, and The Labour Prophet began in May 1893 to include a Cinderella Supplement for children.

7 Labour Prophet, July I 896, 106.

8 Ibid., May $1898,182$.

Ibid., March-April I 894, 4I.

10 Ibid., Oct. $1893,100$. 
III

The committee of the Birmingham Labour Church once resolved "that, in the event of Keir Hardie not being able to lecture, the Town Hall Meeting be dropped." 1 This sentence provides a clue towards understanding the success and failure of the whole movement. Labour Churches gathered large audiences only when they could advertise a popular visiting speaker. Even the few active members who kept each Church alive needed these visits, to reassure them that their work had some point and was making some progress.

The name of Robert Blatchford had drawn to the Manchester Labour Church its first large audience. "I go few places", said Trevor, "where I am not met with the remark: 'It was Nunquam converted me to Socialism.' And it has not been to a new economic theory, merely, that these converts have been introduced. It has been to a new life. Their eyes shine with the gladness of a new birth." ${ }^{2}$ In Blatchford's case it was writing rather than speaking that made eyes shine: his Merrie England won thousands more to socialism than his speeches from Labour Church or I.L.P. platforms. But the effect that Blatchford had in print, others had in person. Philip Snowden, possibly the most gifted speaker among the socialists of the $1890 \mathrm{~s}$, said later that their movement was "something new in politics. It was politics inspired by idealism and religious fervour." 3 The evangelists for socialism expressed, and kindled in others, an enthusiasm comparable with the fervour which had surrounded John Wesley. Ben Tillett, Tom Mann, Keir Hardie, Ramsay MacDonald, Edward Carpenter, J. Bruce and Katharine Glasier, J. R. Clynes, Margaret MacMillan and Caroline Martyn were some of the people who carried the new gospel around Britain between I 890 and 1900 . When they spoke at Labour Churches (as did all the people named here) they drew audiences ten and twenty times as great as could be gathered without them.

Since they had such power to attract and excite crowds, since they preached (in a phrase popular among them) the religion of socialism, and since Labour Churches competed keenly to invite them, it might be concluded that the itinerant speakers were a source of unmixed strength to the Labour Church movement. Yet quite early in the history of the Churches, Trevor was afraid that they were not; and within a few years his fear was communicated to those in the movement who agreed with him about its purpose. One ground for anxiety

1 Birmingham Labour Church, minutes of executive committee meeting, 21 Aug. 1896.

${ }^{2}$ Quoted in A. M. Thompson, op. cit., IOI.

3 Philip Viscount Snowden, An autobiography (1934), I, 7 I. 
about the speakers may be seen from a glance at the subjects of Labour Church addresses: The Drink Traffic; The Future Society; The Labour Problem; Municipal Workshops; The Coming Election; The Kingdom of God is Within You; Religion and Socialism; The Higher Life of a Vegetarian. Deep down, the people who spoke on these varied subjects might share the same vision; but the common denominator was not always easy to detect. "On one Sunday", said a leader of the Nottingham Labour Church, "they would have an orthodox speaker, and perhaps on the next an aggressive secularist. People went away wondering what the Labour Church stood for." 1 Few of the addresses were on subjects which according to the traditional meaning of the word could be called religious. Many socialists, of course, rejected the traditional meaning: a writer in Keir Hardie's Labour Leader called Ben Tillett's attack on the House of Lords, delivered at the Bradford Labour Church, a sermon. ${ }^{2}$ But to Trevor it seemed that the speakers did not understand the soul's deepest need. "Why is it", he asked, "that nearly all our speakers confine themselves almost entirely to questions concerning the conditions of life, and never approach the problem of how to live?" 4 In 1895 the committee of the Labour Church Union, sharing Trevor's dissatisfaction, advised "careful selection" of speakers, urging the Churches to invite "those only who give prominence to the thoughts which underlie our movement and who embody them in personal conduct and life." 5 But it was natural that a Labour Church should go on inviting the people who could best fill a hall, whatever their attitudes to religion. Three years later the secretary at Halifax wrote: "There is a constant outcry against 'economic materialism' as a sole theme in Labour Churches. Most of the present speakers are exponents thereof." 'At black moments Trevor could foresee the Churches being drowned in a torrent of rhetoric, in "the frightful flow of words that there is in our movement compared with the very small amount of real upbuilding work that is being accomplished. One night I lay awake wondering whether it would not be possible to establish silent branches of the Labour Church." "There were even moments when he could blame the speakers for corrupting the movement: "You may get large audiences from Sunday to Sunday

1 Labour Church Record, July i 899, 2.

2 Labour Leader, 29 Dec. I 894, 4.

3 Labour Prophet, Oct. $1893,100$.

4 Ibid., Oct. $1894,136$.

5 Letter from the committee of the Labour Church Union to members of Labour Churches, 1895 , stuck into the minutes of the Birmingham Labour Church.

6 Labour Prophet, Sep. $1898,216$.

7 Ibid., July I 895 , I05. 
with a certain type of attractive speaker who flatters his audience and abuses his opponents; but you will never build up a church in this fashion... such speakers are too frequent among us. They are a rotten foundation to build upon." I At first, Trevor admitted, the Labour Churches had needed rhetoric; but now they wanted organisation and hard work, which the itinerant speakers neither offered on their own behalf nor encouraged in others. James Sims, a leader of the movement who was just as anxious as Trevor that it should be literally a church, urged in 1896 that "Keir Hardie, R. Blatchford, Miss MacMillan, Mrs. B. Glasier, and other prominent personages", be not asked to attend the next conference of the Labour Church Union:

"I know that if they are there they will acquit themselves well, make excellent speeches, give good advice, and be cheered to the echo, and deservedly so; but, when all is over, how much more will the delegates know of each other and of the churches from which they have come? Can these 'prominent personages', most of whom don't belong to any Labour Church, tell us of the difficulties, the trials and obstacles each church has to contend with, and of the various methods adopted to make ends meet?" 2

It was true that most of the "prominent personages" were not members. It is an interesting experiment to search the memoirs of people who were Labour Church speakers for references to the movement. Robert Blatchford, Edward Carpenter, J. R. Clynes, George Lansbury, Tom Mann, James Sexton, Philip Snowden, A. M. Thompson and Ben Tillett all spoke at Labour Churches, and most of them spoke often. Not one mentions the movement in his autobiography: as a distinctive part of the socialist movement, it made too little impression on each man's mind to be considered worth recalling when he looked back across his life. ${ }^{3}$ The Labour Church was simply a congenial and useful platform for them on Sundays. There were people who would not have broken their Sabbath to listen to politics, but who could be got out to hear socialism at what purported to be a religious meeting. Some of the speakers themselves had a Sabbatarian streak which gave them easier consciences on Sundays when addressing a Labour Church than they would have had in exactly the same company at an I.L.P. rally. ${ }^{4}$ The Labour Church label might even

1 Ibid., June $1898, \mathrm{I} 88$.

2 Ibid., March I $896,46$.

3 R. Blatchford, My eighty years (1931); E. Carpenter, My days and dreams (I916); J. R. Clynes, Memoirs, 2 vols. (I 937); G. Lansbury, My Life (1928); Tom Mann's memoirs (1923); J. Sexton, Sir James Sexton, agitator: the life of the dockers' M.P.: an autobiography (1936); Snowden, op. cit.; A. M. Thompson, op. cit.; B. Tillett, Memories and Reflections (1931).

4 See Clynes, op. cit., I, 85 . 
have seemed a protection against the law: Fred Brocklehurst was sent to prison for a month in 1896 for breaking the Sabbath when he spoke on a socialist pitch outside Manchester. ${ }^{1}$

The trouble with the speakers, said one member of the Nottingham Labour Church, was that "they did not build up the membership of the Church." Nottingham had heard clever speakers, giving excellent addresses. "But they never ended their addresses with pointing out to their hearers the nature of the work the Labour Church had to do, and gave no stirring appeal to the audience to join the Church and help forward its work." 2 Why should they? Their eyes were fixed on a social millennium towards which all men would march together as brothers. They were not to be diverted into becoming evangelists for a mere sect, not even for a sect that called itself the Labour Church. Realising this, Trevor searched for other ways of providing his movement with the roots which the speakers were not giving it.

In 1895 Trevor suggested for the first time in The Labour Prophet that the Churches should form Sunday Schools to prepare a second generation of members. ${ }^{3}$ Others echoed this exhortation 4 , and a few Sunday schools were founded (the most active being at Halifax). ${ }^{5}$ But most of the Labour Churches were unwilling or unable to form them. In any case, it was no use training children to take over the movement unless their parents could sustain it in the meantime. If the travelling speakers were not recruiting adult members and organising them, not encouraging in them a sense of belonging together to a religious movement, how else could it be done? "The Labour Church", Trevor decided, "must raise its own speakers and send forth its own missionaries." "From time to time Trevor appealed to "individuals... who shall become living embodiments of the principles for which the Labour Church stands...", "men on whose lips the Living Fire has been placed...", " "ardent and enlightened missionary spirits in our Labour Church movement... Who will prepare themselves for this high calling?"9 He appealed in vain. Usually he called

1 Labour Annual, I 898, 195 .

2 Labour Church Record, July $1899,7$.

' 3 Labour Prophet, July i $895,105$.

4 Ibid., Aug. 1896, 129; June 1897, 90.

5 Ibid., July 1896, r I 9 . There were also a number of "Socialist Sunday Schools" run on similar lines, but apparently in association with I.L.P. branches rather than Labour Churches.

6 Ibid., July 1898,197 .

7 Ibid., May I 894, 56.

- Great Thoughts, 7 Nov. 1896,90 .

- Labour Prophet, Jan. $1894,9$. 
the hypothetical evangelists "missionaries", sometimes "pioneers". Once he remarked that the problem of the Labour Churches was "how to run a church without a minister. I know some of our Churches are feeling it a little difficult. I can only hope it won't be necessary to have anything like a minister." 1 By I 899 Trevor believed himself forced, as a last resort, to fall back on the idea of a clergy. In a paper to the Labour Church Union on "The Raising and Development of Speakers for the Labour Church", Trevor asserted the "necessity, if their movement was to become permanent and effective, of providing a trained body of men for speakers and workers, and especially in the pastoral work of the Labour Churches." It was impossible, he said, to carry on the movement "without setting apart those who were most suitable for such work, and providing them with the means of living." 2 It cannot have surprised Trevor that his suggestion gained no support whatsoever, for he himself had encouraged a hostility to the clergy as an institution. Nor did he explain how the ministers were to be paid by a movement that was virtually bankrupt. This was Trevor's last serious attempt to shape the Labour Churches according to his own vision. In 190 I he retired to a chicken farm; and although he remained friendly to the movement, he was reluctant to offer advice or criticism. "We have a new religious message for the world", he had said in 1899 , "but we have practically no messengers to deliver it..." 3

The president of the Labour Church Union in I902, D. B. Foster, toured the Churches "to find if there was any indication of "God consciousness' amongst them..." He discovered "loud and persistent" demands for economic change, but little interest in "the development of the human soul." 4 Where Labour Churches survived after 1900 it was because local conditions made them convenient mediators between other bodies. The Birmingham Labour Church lasted at least until 1914 for this reason. Its committee said candidly in I 909 :

"As the common meeting ground of men and women representing all sections of the Socialist movement - where the S.D.F. lion may lie down with the I.L.P. lamb and receive the benediction of the Fabian - the Church fulfils an extremely useful purpose." 5

Trevor probably believed that his movement was killed by the

1 Ibid., May 1893,41 .

2 Labour Church Record, July I 899, 6.

a Ibid., April r 899, r.

D. B. Foster, Socialism and the Christ (1921), 33, 50.

${ }^{5}$ Birmingham Labour Church, annual report of executive committee, i 909 . 
secularising impulse. Yet if the Labour Churches had been more exactly what he wanted, it is unlikely that they would have flourished at all. They could draw large audiences for a time, or they could embody and keep pure Trevor's eclectic but distinctive form of religious faith. The demand for that faith was never strong enough for them to do both things at once. Not many people, even within Labour Churches, were interested in them except as one minor means towards a united labour movement. 